\title{
QUASI-JUDICIAL IMIMUNITY: ITS SCOPE AND LIMITATIONS IN SECTION 1983 ACTIONS
}

It has been apparent during the past two years that the principle that no man is above the law remains "the pride and glory of AngloAmerican common law." It is clear that the principle is imtact in the criminal law; however, the competing doctrine of sovereign immunity for public officials creates a greater degree of complexity in the civil law. It is unquestionable that on many occasions a public official who has been deemed liable, and against whom someone has a valid civil claim, will be protected from civil liability by sovereign immunity. The question of most interest to those who may have been injured by the action of a public official is, of course, who is protected by sovereign immunity and to what actions does it extend. ${ }^{2}$

Traditionally the scope of immunity for public officials has been a function of the type of acts performed by the governmental officer concerned. $^{3}$ This Note deals with what have generally been called quasi-judicial officers, those who in broad terms have been regarded as exercising the same sorts of discretionary powers as do judges. ${ }^{4}$ Included within that classification have been such officers as prosecuting

THE FOLLOWING CITATIONS WILL BE USED IN THIS NOTE:

W. HOLDSWORTH, A HISTORY OF ENGLISH LAW (1st ed. 1927) [hereinafter cited as HOLDSWORTH];

W. PROSSER, HANDBoOK OF THE LAW OF ToRTS (4th ed. 1971) [hereinafter cited as Prosser].

1. Jennings, Tort Liability of Administrative Officers, 21 MrNN. L. Rev. 263 (1937). The most obvious examples of the application of the principle are, of course, the cases of President Nixon and Vice President Agnew, both from the executive branch. The trial of Florida Senator Edward Gurney, see N.Y. Times, Feb. 24, 1975, at 38, col. 1 , and the scandal involving the Florida Supreme Court, see id., Apr. 27, 1975, § 1, at 37 , col. 1 , are indications of problems of a similar nature in the legislative and judicial branches.

2. The general question has been the subject of extensive writing by a number of scliolars. See, e.g., Engdahl, Immunity and Accountability for Positive Governmental Wrongs, 44 U. Colo. L. Rev. 1 (1972); Gray, Private Wrongs of Public Servants, 47 CalIf. L. Rev. 303 (1959); Jaffe, Suits Against Governments and Officers: Damage Actions, 77 HaRv. L. REv. 209 (1963); Jaffe, Suits Against Governments and Officers: Sovereign Immunity, 77 HaRv. L. Rev. 1 (1963); James, Tort Liability of Government Units and Their Officers, 22 U. CHI. L. Rev. 610 (1955); Jennings, supra note 1. See also ProsSER $\$ 132$, at 987 n.74.

3. The rank or title of an official las not been regarded as significant in determining whether official immunity is applicable. Note, Official Immunity in Ohio: How to Sue the King's Men, 43 U. CIN. L. REv. 557, 560 (1974).

4. See Jennings, supra note 1, at 276 n.51. 
attorneys, clerks of court, parole board members, and prison officials. ${ }^{5}$ The model of the prosecutor's immumity will be used in this Note as a vehicle to examine the application and scope of official immunity for such quasi-judicial officers. The considerations which are involved in that analysis are basic ones, lowever, and the discussion should be relevant to eacli of the other officers as well. ${ }^{6}$ The precise question that will be examined is the degree of protection to be afforded a quasijudicial state official in a "constitutional tort" action based on section 1983. That section appears to create, in unconditional language, a civil renedy for deprivation of constitutional rights by state or local officers. The Suprene Court has dealt with the same question with

5. The quasi-judicial immunity doctrine developed in the early American case law in the context of common law tort actions. See, e.g., Griffith v. Slinkard, 146 Ind. 117, 44 N.E. 1001 (1896) (malicious prosecution); Stewart v. Case, 53 Minn. 62, 54 N.W. 938 (1893) (assessor valuing property for taxes); Sweeney v. Young, 82 N.H. 159, 131 A. 155 (1925) (school board dismissing a pupil). See also Parker v. Kirkland, 298 IIl. App. 340, 18 N.E.2d 709 (1939) (defamation action against member of tax board of appeals).

A majority of the cases today involve 42 U.S.C. $\& 1983$ (1970). Cases have involved clerks of court, Denman v. Leedy, 479 F.2d 1097 (6th Cir. 1973); Smith v. Rosenbaum, 460 F.2d 1019 (3d Cir. 1972); Davis v. McAteer, 431 F.2d 81 (8th Cir. 1970); Stewart v, Minnick, 409 F.2d 826 (9th Cir. 1969), jurors, White v. Hegerhorse, 418 F.2d 894 (9th Cir. 1969), cert. denied, 398 U.S. 912 (1970); Roberts v. Barbosa, 227 F. Supp. 20 (S.D. Cal. 1964), justices of the peace, Mississippi ex rel. Giles v. Thomas, 464 F.2d 156 (5th Cir. 1972); Pennebaker v. Chamber, 437 F.2d 66 (3d Cir. 1971); Fanale v. Sheehy, 385 F.2d 866 (2d Cir. 1967), and administrative personnel of the courts, Lucarell v. McNair, 453 F.2d 836 (6th Cir. 1972); Gillibeau v. Richmond, 417 F.2d 426 (9th Cir. 1969); Peckham v. Scanlon, 241 F.2d 761 (7th Cir. 1957). But see Stevenson v. Sanders, 311 F. Supp. 683 (W.D. Ky. 1970) (prison officials); United States ex rel. Smith v. Heil, 308 F. Supp. 1063 (E.D. Pa. 1970) (parole boards). Sce note 54 infra for cases dealing with prosecuting attorneys. See also Burkes v. Callion, 433 F.2d 318 (9th Cir. 1970), cert. denied, 403 U.S. 908 (1971); Allison v. California Adult Authority, 419 F.2d 822 (9th Cir. 1969); Silver v. Dickson, 403 F.2d 642 (9th Cir. 1968), cert. denied, 394 U.S. 990 (1969) (parole boards); Sarelas v. Sheehan, 353 F.2d 5 (7th Cir. 1965); Bartlett v. Weimer, 268 F.2d 860 (7th Cir. 1959), cert. denied, 361 U.S. 938 (1960); Holmes v. Silver Cross Hosp., 340 F. Supp. 125 (N.D. Ill. 1972) (appointees of court); Ransom v. Philadelphia, 311 F. Supp. 973 (E.D. Pa. 1970) (prison officials).

6. The model of prosecutorial immunity is an appropriate one, since courts may look to the role of the prosecutor as a standard against which other quasi-judicial functions can be assessed. For instance, in Bricker v. Michigan Parole Bd., 18 Crim. L. REP. 2362 (E.D. Mich. Dec. 18, 1975), a federal court held that parole board members are absolutely immune from section 1983 actions because they act "as an arm of the sentencing judge, just as prosecuting attorneys act in a quasi-judicial capacity in bringing criminal actions." Id. at 2363.

7. 42 U.S.C. $\& 1983$ (1970). The statute reads:

Every person who, under color of any statute, ordinance, regulation, custom, or usage, of any State or Territory, subjects, or causes to be subjected, any citizen of the United States or other person within the jurisdiction thereof to the deprivation of any rights, privileges, or immunities secured by the 
respect to legislators, ${ }^{8}$ judges, ${ }^{8}$ and executive officials, ${ }^{10}$ and has heard oral arguments in a case involving a state prosecutor. ${ }^{11}$ While the case

Constitution and laws, shall be liable to the party injured in an action at law, suit in equity, or other proper proceeding for redress.

The act was originally passed in 1871. Act of Apr. 20, 1871, ch. 22, \& 1, 17 Stat. 13. 8. Tenney v. Brandhove, 341 U.S. 367 (1951). See notes $21-22$ infra and accoinpanying text.

9. Pierson v. Ray, 386 U.S. 547 (1967). See note 23 infra and accompanying text.

10. Scheuer v. Rhodes, 416 U.S. 232 (1974). See notes 28 \& 30 infra and accompanying text.

11. Imbler v. Pachtman, 500 F.2d 1301 (9th Cir. 1974), cert. granted, 420 U.S. 945 (1975). See notes 40-46 infra and accompanying text. The case was argued on November 3, 1975. 44 U.S.L.W. 3273 (U.S. Nov. 11, 1975).

Ed. Note. As this Note went to press, the Supreme Court affirmed the Ninth Circuit opinion in Imbler, granting state prosecutors absolute immunity under section 1983. Imbler v. Pachtman, 44 U.S.L.W. 4250 (U.S. Mar. 2, 1976). The Court noted that "[t]he public trust of the prosecutor's office would suffer if he were constrained in making every decision by the consequences in terms of his own potential liability in a suit for damages." Id. at 4255.

Time considerations prevent an extensive analysis of the Court's decision; however, several observations can be offered. The general issue of quasi-judicial immunity has not been settled by the decision. The Court did not focus on the nature of the quasijudicial officer's duties. Rather, it was concerned with the special role the prosecutor plays in the judicial system. By treating the prosecutor as sui generis, the Court has provided little insight into the degree of immunity to be afforded other quasi-judicial officials.

Insofar as prosecutorial immunity is concerned, several points made in Imbler should be examined. First, discussion of the impact of Scheuer upon the entire immunity issue is conspicuously absent. As noted below, Scheuer, in providing executive officers with only a qualified immunity, represented a break with previous cases which had extended absolute immunity to executive officials. See notes 14-17 infra and accompanying text. In Scheuer, however, the Court cited the same basic policy reasons which had previously been used to support absolute immunity. See note 36 infra. The Imbler decision appears to rest essentially ou public policy grounds. See 44 U.S.L.W. 4250, 4254-55 (U.S. Mar. 2, 1976). The only attempt to distinguish the prosecutor from other executive officials is made in a few lines which indicate that a prosecutor is "[f]requently acting under serious constraints of time and even information, . . . [and is] responsible annually for hundreds of indictments and trials," and that consequently there is greater opportunity for making decisions which "could engender colorable claims of constitutional deprivation." Id. at 4255. The Scheuer Court, however, recognized that executive officers, too, must "often act swiftly and firmly ... [and] . . . are entitled to rely on traditional sources for the factual information on which they decide and act." Scheuer v. Rhodes, 416 U.S. 232, 246 (1974). Furthermore, never before have courts considered the frequency of potential claims to be a significant factor in distinguishing the type of immunity to be afforded public officials; policemen, for instance, subject themselves daily to such potential actions. Rather, the emphasis has been on the nature of the activity performed. On these terms, the public policy rationale breaks down as a means of distinguishing one official's immunity from another's. See notes 63-64 infra and accompanying text. Mr. Justice White makes the same point in his concurring opinion in $1 \mathrm{mbler}$, although he does articulate one policy reason which permitted him to concur: the possibility of injury to the governmental decision-making process from the threat of suit. 44 U.S.L.W. at 4258-59. Certainly the officials considered in the 
involving the prosecutor is directly related to the issues to be considered here, those concerning judges and executive officials are also of key importance, for the crux of the problem is whether quasi-judicial officials should be afforded an absolute immunity from suit, as are judges, ${ }^{12}$ or whether they should be protected by a qualified immunity, such as that shielding executive officials. ${ }^{13}$

Until 1974, there was no real difficulty in ascertaining the scope of the immunity available to quasi-judicial officials in section 1983 actions. In that year, however, the Supreme Court decided in Scheuer $v$. Rhodes $^{14}$ that even the highest executive officials of a state ${ }^{15}$ were protected, not by an absolute immunity, but by a qualified immunity in section 1983 suits. The reasons advanced in Scheuer for the granting of a qualified imnunity to high executive officials were similar to the "basic pohicy considerations" which support immunity for judicial and

Scheuer case are deeply involved in the governmental decision-making process, however, and the Court there felt that qualified immunity was adequate.

Second, the Court stated that if a prosecutor were afforded only qualified immunity there would be an "adverse effect upon the functioning of the criminal justice system." Id. at 4255 . The focus is thereby shifted from the traditional rationale for quasi-judicial immunity dealing with the nature of the prosecutor's functions to considerations dealing with the protection of the system. Extending absolute immunity on this basis would exceed limits heretofore established by the courts. See note 134 infra. To be consistent, absolute immunity would also have to be extended to protect defense attorneys from malpractice suits based on their actions during the trial, as under the English rule which has not been followed in this country. See note 134 infra. Moreover, shifting the focus away from the nature of the acts performed operates to carve out an exception for the prosecutor, making it difficult, if not impossible, to extend the Court's rationale to other quasi-judicial officers who are not as closely connected to the criminal justice system.

Third, the Court notes that even though a prosecutor is absolutely immune from civil suit, he still may be criminally liable and may be disciplined by an association of his peers. 44 U.S.L.W. at 4256 . As to criminal liability, other executive officials are, of course, equally susceptible. The availability of professional discipline as a remedy may deter future misconduct, but it does not provide the victim of misconduct with the type of redress contemplated by section 1983.

In light of the difficulty in extending the Imbler rationale to other quasi-judicial officials, and the fact that Hilliard v. Williams, 516 F.2d 1344 (6th Cir.), petition for cert. filed, 44 U.S.L.W. 3120 (U.S. Sept. 9, 1975), is still pending before the Court, it seems apparent that the issue of quasi-judicial immunity is far from being settled.

12. See note 23 infra and accompanying text.

13. See notes $29-35$ infra and accompanying text.

14. 416 U.S. 232 (1974).

15. The Scheuler Court did not address the question of whether an absolute or a qualified immunity is available to high-ranking federal officials in tort actions. The Court of Appeals for the District of Columbia has since held that high officials of the United States Department of Justice did not enjoy an absolute immunity from section 1983 liability for their participation in law enforcement activities in the District. Apton v. Wilson, 506 F.2d 83 (D.C. Cir. 1974); see Burkhart v. Saxbe, 397 F. Supp. 499, 503 (E.D. Pa. 1975). 
legislative officials as well:;i ${ }^{16}$ nevertheless, the Supreme Court decided on a qualified immunity. In so doing, it signaled the end of a trend toward absolute immunity for virtually all government officers which had developed during the first two thirds of the twentieth century. ${ }^{17}$

The question after Scheuer is how far the implication of that decision-that the traditional policy reasons for immunity from tort liability justify only a qualified immunity-will reaclı outside the executive brancli of government. Indeed, one might argue persuasively that the immunity of judges (or of legislators) should be qualified, since the same rationale is advanced as in the case of executive officials. ${ }^{18}$ That argument, however, is foreclosed unless the Supreme Court reconsiders its prior pronounceinents. ${ }^{19}$ There is thus an absolute immunity for judges in section 1983 actions, but only a qualified immunity for state executive officers. The issue of the scope of immunity for quasi-judicial officials is squarely at the point of conflict between traditional judicial immunity and the restricted immumity contemplated in Scheuer. The outcome of the debate over which camp officials like prosecuting attorneys are to occupy will not only have considerable significance in its own right, but inay provide an indication of how far the courts are willing to extend the rationale of Scheuer.

\section{OFFICIAL IMMUNITY FROM CIVIL LIABILITY: General Considerations}

A public officer's defense of immunity ${ }^{20}$ from civil suit may be either absolute or qualified. An absolute immunity protects a defendant

16. Note, Official Immunity, supra note 3, at 577 .

17. See note 37 infra and accompanying text. The reversal was foreshadowed in Bivens v. Six Unknown Named Agents, 403 U.S. 388, on remand, 456 F.2d 1339 (2d Cir. 1972). See also Monroe v. Pape, 365 U.S. 167 (1961). The Court had already held, in Pierson v. Ray, 386 U.S. 547 (1967), that policemen were protected by a qualified immunity. Policemen have traditionally been treated in a separate category from other executive officials, however, insofar as immunity from civil suit is concerned. See Scheuer v. Rhodes, 416 U.S. 232, 244-45 (1974).

18. Spalding v. Vilas, 161 U.S. 483, 498 (1896); see Note, Official Immunity, supra note 3 , at 560 .

19. The absolute immunity of judges in section 1983 suits was reaffirmed in Pierson v. Ray, 386 U.S. 547 (1967). The Court upheld absolute immunity for legislators in Tenney v. Brandhove, 341 U.S. 367 (1951).

20. There are conflicting views on whether such a defense is properly termed an "immunity" or a "privilege." Professor Engdahl, for example, contends that the use of the term "immunity" is improper because that concept goes to a court's jurisdiction rather than to the merits of the claim. Engdahl, supra note 2, at 41 n.195. Conversely, Dean Prosser argues that "immunity" is more satisfactory since the concept "avoids liability in tort under all circumstances, within the limits of the immunity itself; and is conferred, not because of the particular facts, but because of the status or position of the 
without regard to his purpose, motive, or the reasonableness of his conduct. The protection of a qualified immunity depends upon the defendant's good faith and the reasonableness of his behavior. Whether a public official is protected by absolute or qualified immunity depends upon what office he holds and what functions he performs. Legislators, for example, enjoy an absolute immunity when acting within the scope of their legislative duties, ${ }^{21}$ and such imnunity is explicitly conferred on federal congressmen by the Constitution "for any Speech or Debate in either House." ${ }^{22}$ It is equally well settled that the immunity afforded judges for official acts is absolute despite the absence of a constitutional provision comparable to the one protecting legislators. ${ }^{23}$ Absolute immumity in this context, however, presents a unique problem owing to the fact that the immunity has been said to be available not only to judges, but also to "judicial officers." 24 Just who fills the role of a "judicial officer" is not clear. ${ }^{25}$ On the other hand, it has been held that executive officers are not protected by absolute immunity; even at common law their protection is only qualified, the immunity granted being a function of the amount of discretion in decision-making which a particular officer possesses. ${ }^{28}$

Although a contrary result has been urged, ${ }^{27}$ it is also clear that these same common law immunities protect government officials in

... defendant . ..." Prosser 970. The term "immunity" is used throughout this Note, since it is the term that most courts have used in recent years. See, e.g., Wood v. Strickland, 420 U.S. 308, 320-22 (1975); Scheuer v. Rhodes, 416 U.S. 232, 238 (1974).

21. Tenney v. Brandhove, 341 U.S. 367 (1951) (holding that the common law doctrine protects legislators independently of constitutional provisions). See also $E x$ parte Wason, L.R. 4 Q.B. 573 (1869); Dillon v. Balfour, 20 L.R. Ir. 600 (Ex. 1887).

22. U.S. Consr. art. I, $\S 6$. This section has been broadly construed by the courts. See Kilbourn v. Thompson, 103 U.S. 168 (1880); McGovern v. Martz, 182 F. Supp. 343 (D.D.C. 1960) (absolute immunity in defamation suit based on written extensions of Congressman's remarks in Congressional Record appendix). Similar provisions are contained in many state constitutions. See Tenney v. Brandhove, 341 U.S. 367, 375 n.5 (1951) (enumerating state constitutional provisions).

23. See Bradley v. Fisher, 80 U.S. (13 Wall.) 335 (1871); Randall v. Brigham, 74 U.S. (7 Wall.) 523 (1868); Wilkes v. Dinsman, 48 U.S. (7 How.) 89, 129 (1849).

24. See, e.g., Barr v. Matteo, 360 U.S. 564, 569 (1959); Bradley v. Fisher, 80 U.S. (13 Wall.) 335, 347 (1871).

25. Indeed, this ambiguity contributes to the problem of the scope of quasi-judicial immunity. See notes 103-29 infra and accompanying text.

26. Scheuer v. Rhodes, 416 U.S. 232, 247-48 (1974). After pointing out that both legislative and judicial immunity had deep roots in the counmon law, the Court stated that "[t]he immunity of the Crown has traditionally been of a more limited nature." Id. at 239 n.4.

27. Pierson v. Ray, 386 U.S. 547, 558-59 (1967) (Douglas, J., dissenting); see Kates, Immunity of State Judges Under the Federal Civil Rights Acts: Pierson v. Ray 
actions based on section $1983 .{ }^{28}$ Scheuer $v$. Rhodes ${ }^{29}$ stands out among the cases which have extended common law immunities to section 1983 actions because the Court held for the first time that state executive officials are protected only by a qualified immunity. Indeed, as late as 1959 it had been held that all executive officials were protected by absolute immunity in defamation suits. ${ }^{30}$

The Scheuer case arose out of the civil disorder at Kent State University in 1970. Section 1983 actions were brought agamst, inter alia, the Governor of Ohio by the personal representatives of the estates of three students who died in the disorder. The Sixth Circuit Court of Appeals affirmed a dismissal of the conıplaints, ${ }^{31}$ but the Supreme Court reversed." After noting that "[t]he immunity of the Crown has

Reconsidered, 65 Nw. U.L. REv. 615 (1970). Professor Kates cites congressional debates to argue that the issue of liability imposed by section 1983 was identical to that of the criminal liability imposed by 18 U.S.C. $\$ 242$. Id. at 621-22. After noting that on at least two occasions amendinents to delete the imposition of criminal liability of state judges were unsuccessfully introduced, the author concludes that "the proposition that $\$ 1983$ leaves the common law of judicial immunity intact (while the statute upon which it was consciously modeled abrogates it) approaches the incredible." Id. at 62223. But see Comment, Federal Comity, Official Immunity, and the Dilemma of Section 1983, 1967 DUKE L.J. 741, 778 (at least "some inferential support for judicial immunity" in the debates). See also Note, Liability of Judicial Officers Under Section 1983, 79 YALE L.J. 322 (1969). The conflicting interpretations of the debate indicate that it is extremely difficult to determine congressional intent from legislative history. $C f$. Palmer v. Thompson, 403 U.S. 217, 226 (1971); United States v. Constantine, 296 U.S. 287, 291 (1935).

28. Wood v. Strickland, 420 U.S. 308, 318 (1975) (executives); Scheuer v. Rhodes, 416 U.S. 232 (1974) (executives); Pierson v. Ray, 386 U.S. 547 (1967) (judges); Tenney v. Brandhove, 341 U.S. 367 (1951) (legislators). In all the cases it was emphasized that there were strong common law traditions supporting the immunity and that if Congress had intended to abrogate those immunities by the passage of section 1983 it would have specifically so provided. See Pierson v. Ray, 386 U.S. 547, 554-55 (1967); Tenney v. Brandhove, 341 U.S. 367, 376 (1951). In Tenney the Court even considered it a big assumption that Congress has the constitutional power to linit the freedom of state legislators acting within the sphere of their duties. Id. at 376.

29. 416 U.S. 232 (1974).

30. Barr v. Matteo, 360 U.S. 564, 576 (1959). The same conduct which is the basis of a common law defamation action can support a section 1983 suit when it is alleged that the dissemination of slanderous remarks makes it impossible for a defendant to receive a fair trial. See Williams v. Gorton, Civil No. 74-2627 (9th Cir. Jan. 19, 1976).

Although Barr dealt with federal officials and Scheuer was concerned with state officials, the distinction is not significant for immunity purposes. See Apton v. Wilson, 506 F.2d 83 (D.C. Cir. 1974). See also McManis, Personal Liability of State Officials Under State and Federal Law, 9 GA. L. REv, 821, 832-33, 836 n.70 (1975).

31. 471 F.2d 430 (6th Cir. 1972).

32. The Court's reversal was based not only on the section 1983 claim, but also on the circuit court's holding that the claim was blocked by the eleventh amendment. 416 U.S. at 237-38. That amendment provides that "[t]he Judicial power of the United States shall not be construed to extend to any suit in law and equity, commenced or 
traditionally been of a more limited nature [than that afforded legislators and judges]"3s and that police officers have never been shielded by absolute immunity, ${ }^{34}$ the Court concluded that the Governor, as a high executive official, would have less protection than the legislator or judge but more protection than the police officer. The quantum of protection the executive officers would receive depended upon several factors: (1) the scope of the official's discretion and responsibility; (2) all the circumstances surrounding a particular incident; (3) the reasonableness of the official's action; and (4) a good faith belief that the action was proper. ${ }^{85}$

It is apparent that the Scheuer decision does not extend so far as to reach officials who are protected by either judicial or legislative immunity. $^{30}$ It is equally obvious, however, that Scheuer undermines the

prosecuted against one of the United States by Citizens of another State . . ." While the amendment by its terms does not bar suits against a state by its own citizens, the Supreme Court has consistently held that an unconsenting state is immune from suits brought in federal courts by its own citizens as well as by citizens of another state. See Hans v. Louisiana, 134 U.S. 1 (1890). The Court has also recognized that a suit may not be brought in many cases where the state itself is not a named party.

It is ... . well established that even though a State is not named a party to the action, the suit may nonetheless be barred by the Eleventh Amendment. In Ford Motor Co, v. Department of Treasury, . . . the Court said: "[W] tho action is in essence one for the recovery of money from the state, the state is the real, substantial party in interest and is entitled to invoke its sovereign immunity from suit even though individual officials are nominal defendants." Edelman v. Jordan, 415 U.S. 651, 663 (1974), quoting Ford Motor Co. v. Department of Treasury, 323 U.S. 459 , 464 (1945).

The Scheuer Court held that the complaint involved in the case at bar was not directed at the state, but at the individual defendants, and that the state was not the real party in interest. 416 U.S. at 238.

33. 416 U.S. at $239-40$ n.4. The Scheuer Court was not the first to look to the common law to support absolute immunity for judges. See Pierson v. Ray, 386 U.S. 547, 553-54 (1967); Yates v. Lansing, 5 Johns. 282, 291 (N.Y. Sup. Ct. 1810). In so doing, the Scheuer Court was able to circumvent the difficulty of explaining on policy grounds why judges receive a stepped-up immunity that executive officials do not enjoy.

34. 416 U.S. at $244-45$.

35. Id. at 247-48. It is significant that the Court pointed out that section 1983 "would be drained of meaning were we to hold that the acts of a governor or other high executive officer have the quality of supreme and unchangeable edict, overriding all conflicting rights of property and unreviewable through the judicial power of the Federal Government.' " Id. at 248. Nevertheless, the sliding scale of immunity would appear to provide high-ranking executive officials, such as governors, with almost absolute protection.

36. It is the Court's footnote reference to the different common law basis of judicial immunity that makes it "apparent" that the decision would not reach judges. See note 33 supra and accompanying text. It would be far from apparent without that footnote that the decision would not affect judicial immunity insofar as the same policy reasons which had supported absolute immunity for judicial officials were used by the Court to support the limited immunity for executives. See note 63 infra. Cf. Spalding v. Vilas, 161 U.S. 483, 498 (1896). 
rationale of previous decisions which had extended absolute immunity into the executive branch. ${ }^{37}$ Those cases held that "the same general considerations of public policy and convenience" 38 which provided $a b-$ solute judicial immunity applied to executive officials. ${ }^{39}$ Judicial immunity thus provided the foundation fron which absolute executive immunity began. Scheuer, then, nust be read to mean the extension has gone too far, and that absolute judicial immunity should be confined to its original boundaries so as to protect only "judicial officers." The difficulty now is in staking out the boundaries of the appropriate class of "judicial officers."

\section{The Development of Quasi-Judicial Immunity}

The problems in the area of quasi-judicial immunity are vividly revealed in two recent court of appeals decisions which reached conflicting results in similar fact situations. In Imbler v. Pachtman, ${ }^{40}$ the Ninth Circuit Court of Appeals held that a state prosecutor was absolutely immune froin a section 1983 civil suit. The plaintiff, Imbler, had been convicted of nurder in 1961. After an unsuccessful attempt to obtain a writ of liabeas corpus in the state courts, his petition was finally granted

37. See Barr v. Matteo, 360 U.S. 564 (1959); Spalding v. Vilas, 161 U.S. 483 (1896); Gregoire v. Bỉddle, 177 F.2d 579 (2d Cir. 1949), cert. denied, 339 U.S. 949 (1950).

38. Spalding v. Vilas, 161 U.S. 483,498 (1896).

39. Spalding involved an allegation that the Postmaster General had maliciously caused the plaintiff to suffer $\$ 100,000$ in damages. While holding that the Postmaster General was absolutely inmune from civil suit, the Court limited its opinion to heads of executive departments. Id. at 498.

Spalding was extended by Gregoire v. Biddle, 177 F.2d 579 (2d Cir. 1949), cert. denied, 339 U.S. 949 (1950), a decision which, though not from the Supreme Court, was "in addition to being considered a landmark by other lower courts, . . . appear[ed] to be so regarded by the Supreme Court." Kelley v. Dunne, 344 F.2d 129, 132 n.5 (1st Cir. 1965).

The defendants in Gregoire were two successive attorneys general of the United States, two successive directors of the Enemy Alien Control Unit of the Department of Justice, and the District Director of Immigration at Ellis Island. The two attorneys general were the only ones of the five who were heads of executive departments. The other three defendants were lower echelon executive officials who, nevertheless, were deemed to be shielded from civil suit, regardless of their notives. 177 F.2d at 580 . For a listing of earlier cases which supported the Gregoire holding, see id. at 581 n.11.

Gregoire was echoed in Barr. The plurality stated flatly that it did not think "the principle announced in Vilas can properly be restricted to executive officers of cabinet rank . . .," citing several lower court opinions in support of that view. 360 U.S. at 572 \& n.9. Chief Justice Warren and Justice Brennan wrote stinging dissents, objecting to the extension of Spalding v. Vilas to low-ranking executive officials. Id. at $583,587$. The effect of these three decisions was clearly to protect any government official who exercised discretion in decision-making.

40. 500 F.2d 1301 (9th Cir. 1974), cert. granted, 420 U.S. 945 (1975). 
by a federal district court more than eight years later. ${ }^{41}$ The basis for the federal court's holding was that Imbler's conviction had been secured in part by testimony the prosecutor knew, or had strong reason to know, was perjured. ${ }^{2}$

Imbler brought a suit against the prosecutor for damages based on section 1983. There was no question that the prosecutor's actions, as found by the district court in the habeas corpus proceedings, violated the defendant's right to due process of law under the fourteenth amendment. ${ }^{43}$ The district court nevertheless dismissed the complaint, holding that a prosecuting attorney was protected by an absolute immunity for acts committed "in the performance of duties constituting an integral part of the judicial process." ${ }^{44}$ The court held further that the actions by Prosecutor Pachtman undoubtedly were within his prosecutorial duties since the constitutional violation occurred during the questioning of witnesses and the presentation of testimony at trial. ${ }^{45}$ The dismissal was affirmed by the Nimth Circuit Court of Appeals. ${ }^{46}$

The second case was Hilliard $v$. Williams from the Sixth Circuit. ${ }^{47}$ Mrs. Hilliard, too, had been convicted of murder. The conviction was reversed on the grounds that the prosecutor had withheld evidence from the trial which he knew would be exculpatory. Moreover, the prosecutor had presented "false and misleading" testimony related to the same piece of evidence. ${ }^{48}$

Mrs. Hilliard was subsequently retried, the exculpatory evidence was introduced, and she was acquitted. She then brought a section 1983 action against the prosecutor, contending that he had violated her

41. Imbler v. Craven, 298 F. Supp. 795 (C.D. Cal. 1969), aff'd sub nom. Imbler v. California, 424 F.2d 631 (9th Cir.), cert. denied, 400 U.S. 865 (1970).

42. 298 F. Supp, at 800 .

43. See Mooney v. Holohan, 294 U.S. 103, 112 (1935) (conviction procured by state through knowing use of perjured testimony and withholding of exculpatory evidence "is as inconsistent with the rudimentary demands of justice as is the obtaining of a like result by intimidation"); accord, Napue v. Illinois, 360 U.S. 264 (1959); Alcorta v. Texas, 355 U.S. 28 (1957); Pyle v. Kansas, 317 U.S. 213 (1942).

44. See Imbler v. Pachtman, 500 F.2d 1301, 1302 (9th Cir. 1974).

45. See id. at 1302-03.

46. 500 F.2d 1301 (9th Cir. 1974).

47. 516 F.2d 1344 (6th Cir. 1975).

48. The evidence involved was a blood-stained jacket and some blood-stained curtains. The State alleged that the blood was that of the murder victim. Prior to trial both items were sent to the FBI laboratory in Washington for analysis. The lab returned a report indicating that the blood on the two items was not human blood. Neither the report nor the jacket and curtains were introduced into evidence at the trial. The prosecutor, moreover, allowed testimony to the effect that the blood appeared to be that of a human, in spite of the FBI report that it definitely was not human blood. Id. at $1345-48$. 
right to due process. As in the Imbler case, the district judge originally dismissed the complaint on the ground that the prosecutor was absolutely immune from suit. ${ }^{49}$ After a series of appeals and remands, ${ }^{50}$ the Sixth Circuit Court of Appeals reversed, holding that "[i]t is most emphatically not within the scope of a prosecuting attorney's duties to withhold exculpatory evidence and to direct witnesses to give misleading and deceptive testimony."

Most of the lower courts which have dealt with the problem of prosecutorial immunity from suit under section 1983 have held that the protection is absolute. ${ }^{62}$ The Hilliard case stands alone among federal court of appeals decisions in explicitly holding that a bad faith act, even in the course of a trial, may lead to section 1983 liability. ${ }^{63}$

49. Id. at 1348.

50. The case originally reached the court of appeals in 1972, 465 F.2d 1212 (6th Cir.), cert. denied, 409 U.S. 1029 (1972), where it reversed the district court's decision on quasi-judicial immunity and remanded. On remand, the district court concluded that the prosecutor's acts had not been shown to be the proximate cause of Mrs. Hilliard's conviction, see 516 F.2d at 1349, and that his conduct had thus not deprived her of any constitutional right. On appeal from this holding, the Sixth Circuit again reversed, holding that the plaintiff's constitutional rights had in fact been violated, $i d$., and reaffirming that immunity was no defense. Id. at 1350 . The prosecutor, District Attorney General John L. Williams, filed a petition for certiorari on August 21, 1975. 44 U.S.L.W. 3208 (U.S. Oct. 7, 1975). The petition for certiorari of his co-defendant, Tennessee Bureau of Criminal Investigation Agent Donn Clark, was denied. 44 U.S.L.W. 3391 (U.S. Jan. 13, 1976).

51. 516 F.2d at 1350 .

52. See, e.g. Tyler v. Witkowski, 511 F.2d 449 (7th Cir. 1975) (false imprisonment); Duba v. McIntyre, 501 F.2d 590 (8th Cir. 1974) (malicious prosecution and false arrest); Guerro v. Mulhearn, 498 F.2d 1249 (1st Cir. 1974) (illegal wiretap and use of perjured testimony); Guerrero v. Barlow, 494 F.2d 1190 (5th Cir. 1974) (false imprisonment); United States ex rel. Moore v. Koelzer, 457 F.2d 892 (3d Cir. 1972) (use of false evidence); Madison v. Gerstein, 440 F.2d 338 (5th Cir. 1971) (malicious prosecution and false arrest); Arensman v. Brown, 430 F.2d 190 (7th Cir. 1970) (plaimtiff seeking injunction from prosecution); Dacey v. New York County Lawyers' Ass'n, 423 F.2d 188 (2d Cir. 1969), cert. denied, 398 U.S. 929 (1970) (denial of freedom of speech); Kauffman v. Moss, 420 F.2d 1270 (3d Cir.), cert. denied, 400 U.S. 846 (1970) (use of perjured testimony); Marlowe v. Coakley, 404 F.2d 70 (9th Cir.), cert. denied, 395 U.S. 947 (1968) (use of perjured testimony and withholding exculpatory evidence before grand jury); Bauers v. Heisel, 361 F.2d 581 (3d Cir. 1966), cert. denied, 386 U.S. 1021 (1967) (deprivation of liberty and denial of right to speedy trial).

53. In Weathers v. Ebert, 505 F.2d 514 (4th Cir. 1974), the Fourth Circuit Court of Appeals noted the holding in Hilliard and stated that "Hilliard represents a real, but very limited, departure from the traditional rule of prosecutorial immunity." Id. at 516 . The court did not have to decide whether to follow Hilliard, however, since the complaint in the case was broad enough to include merely negligent, as well as malicious, behavior by the prosecutor. Id. Dicta in a recent Second Circuit decision indicate that that court may no longer grant absolute immunity for any prosecutorial functions. Martin v. Merola, Civil No. 75-7113 (2d Cir. Feb. 5, 1976). 
The foundation for an absolute prosecutorial immunity in section 1983 actions was established by the 1926 decision of the Second Circuit in Yaselli v. Goff. ${ }^{54}$ The complaint in Yaselli was based on an allegedly malicious prosecution by a special assistant to the United States Attorney General. In holding that the defendant was absolutely immune from suit, the court indicated that among the "weighty reasons" why the prosecutor should be protected "in the proper discliarge of .... [his] official duties" was the fact that his duties were of a judicial nature and that the due execution thereof depended upon his own judgment. ${ }^{55}$ Drawing support from the immunity protecting justices of the peace, grand jurors, and participants in judicial proceedings, the court concluded that the same considerations dictated a similar protection for the United States attorney in the case before it. "A United States attorney, if not a judicial officer, is at least a quasi judicial officer, of the government. He exercises important judicial functions, and is engaged in the enforcement of the law."

The Supreme Court summarily affirmed the Yaselli decision. ${ }^{67}$ Judge Learned Hand wrote many years later that the Yaselli affirmance made the conclusion inevitable that "officers of the Department of Justice, when engaged in prosecuting private persons, enjoy the same absolute privilege as judges." 58 It should be recognized, however, that the Supreme Court action came during the period when absolute immunity was the rule for officials of all branclies of government. ${ }^{59}$ The fact that the Yaselli affirmance was granted summarily, coupled with the reversal of the trend toward across-the-board absolute immunity evi-

54. 12 F.2d 396 (2d Cir. 1926), aff'd per curiam, 275 U.S. 503 (1927). Yaselli was certainly not the first case to provide the prosecutor with absolute immunity, however. Many state court decisions had so held. See Griffith v. Slinkard, 146 Ind. 117, 44 N.E. 1001 (1896), where is was stated that "[n]o public officer is responsible in a civil suit for a judicial determination, however erroneous it may be, and however malicious the motive which produced it." Id. at 121, 44 N.E. at 1002, quoting J. TownsHEND, A Treatise on the Wrongs Called Stander \& Libel $\$ 227$, at 396 (3d ed. 1877); cf. Carpenter v. Sibley, 153 Cal. 215, 94 P. 879 (1908) (nnalicious prosecution); Arnold v. Hubble, 18 Ky. L. Rptr. 947, 38 S.W. 1041 (1897) (where; however, the suggestion is clear that if the prosecutor acted maliciously he would be liable); Schneider v. Shepherd, 192 Mich. 82, 158 N.W. 182 (1916) (false imprisonment). See also Smith v. Parman, $101 \mathrm{Kan} .115,165$ P. 663 (1917) (malicious prosecution); Kittler v. Kelsch, 56 N.D. 227,216 N.W. 898 (1927) (malicious prosecution); Watts v. Gerking, 111 Ore. 641, 228 P. 135 (1924) (malicious prosecution); Annot., 56 A.L.R. 1255 (1928).

55. 12 F.2d at 399.

56. Id. at 404.

57. 275 U.S. 503 (1927).

58. Gregoire v. Biddle, 177 F.2d 579, 580 (2d Cir. 1949), cert. denied, 339 U.S. 949

(1950). See cases cited in note 52 supra.

59. See notes 28-30 supra and accompanying text. 
denced in Scheuer, indicates that Yaselli should no longer be viewed as strong Suprenie Court precedent for an absolute quasi-judicial immunity.

In spite of the questions about the appropriateness of an absolute prosecutorial immunity stenuming froni Scheuer, sonie courts continue to treat the issue as settled by precedent and refuse to examine the specific factual context in which the immunity is asserted. ${ }^{60}$ Pre-Scheuer cases typically considered the office of prosecutor to be vested with "a vast quantun of discretion," 11 which nuust be protected in order to permit prosecutors to serve the public's best interest. Opinions frequently relied upon the traditional policy arguments which are advanced in support of immunity for public officials in general: the importance of pronipt and fearless decision-making, the danger of influencing officials by threat of lawsuit, the deterrent effect upon those considering entering public life, and the drain on the time of officials in defending frivolous suits. ${ }^{62}$ None of these argunients, however, distinguishes between an absolute and a qualified immunity, nor offers an explanation for treating prosecutors differently from other members of the executive branch. ${ }^{63}$

It is of course important for any public officer to feel that he niay act decisively and without intimidation in the performance of his official functions. $^{64}$ The problems concerning the deterrent effects and time drains also appear applicable to all officials. Thus, in ternis of the policy reasons which have been relied upon as a rationale for protecting public officials fronı civil suit, it makes no difference whether the particular officer involved is a high-ranking executive, a low-ranking executive, a policeman, a legislator, or a judge. Any one of those individuals who does not make decisions when necessary does not fully and faithfully perforns the duties of his office. Consequently, the traditional rationales tend to prove too nruch when one is concerned not

60. See Tyler v. Witkowski, 511 F.2d 449 (7th Cir. 1975); Imbler v. Pachtman, 500 F.2d 1301 (9th Cir. 1974). See also Boyd v. Adams, 513 F.2d 83, 85-86 (7th Cir. 1975).

61. Bauers v. Heisel, 361 F.2d 581, 590 (3d Cir. 1966).

62. See, e.g., Spalding v. Vilas, 161 U.S. 483 (1896); Bradley v. Fisher, 80 U.S. (13 Wall.) 335 (1871); Bauers v. Heisel, 361 F.2d 581, 590 n.9 (3d Cir. 1966); cf. Scheuer v. Rhodes, 416 U.S. 232 (1974). See also Jaffe, Damage Actions, supra note 2, at 219 22; Jennings, supra note 1, at 271-72; Note, The Proper Scope of the Civil Rights Acts, 66 HARV. L. REv. 1285, 1295 n.54 (1953).

63. Indeed, the difficulties with the rationale are well illustrated by the fact that the Supreme Court in Scheuer v. Rhodes employed the traditional policy reasons to support its decision that executive officials should have only qualified immunity. 416 U.S. 232, 241-42 (1974); see Note, Official Immunity, supra note 3, at 577.

64. See Jaffe, Damage Actions, supra note 2, at 219-22. 
with public officials in general, but with a specific segment of that entire group. The public policy rationale does not suffice to explain why judges have been given absolute immunity while executive officials are shielded by only a qualified protection. That rationale, therefore, provides little insight into the question of which type of immunity the quasijudicial officer should have.

While some courts, then, have not dealt squarely with the implications of the trend away from absolute immunity for all public officials illustrated in Scheuer, there has been an erosion of the immumity afforded prosecutors. That erosion has been accomplished through a narrowing of the category of activities in which prosecutors enjoy the protection of immunity. In 1974, a federal district court was able to identify "a growing trend toward determining the applicability of quasi-judicial immunity by analyzing the nature of the activity being performed." ${ }^{85}$ Where functions are "closely aligned" with the judicial process-such as the prosecution of trials and grand jury proceedings-an absolute immunity still shields prosecutors. Where, lowever, the nature of the activity is further removed from the actual courtroom process, the inımunity is qualified like that of other executive officials. ${ }^{66}$ Thus, courts have refused to allow a defense of absolute immunity for prosecutors for acts done while directing police investigative activity, ${ }^{67}$ committing perjury when questioned by a judge, ${ }^{68}$ and ordering illegal wiretaps. ${ }^{60}$

A pre-Scheuer case decided by then Circuit Judge, now Justice Stevens illustrates this functional approach to the applicability of absolute prosecutorial immunity. In Hampton $v$. City of Chicago, ${ }^{70}$ members of the Black Panther party brought a section 1983 action against fourteen police officers and several state's attorneys following a raid on the apartment of a Black Panther member. Two residents of the apartinent were killed in the raid. ${ }^{71}$ The plaintiffs alleged that two state's attorneys "planned the raid and agreed to use excessive and deadly force" against the residents, for the purpose of depriving the plaintiffs of their first amendment rights. The district court denied a

65. Briggs v. Goodwin, 384 F. Supp. 1228, 1230 (D.D.C. 1974).

66. Id.; see Apton v. Wilson, 506 F.2d 83, 91 (D.C. Cir. 1974).

67. Apton v. Wilson, 506 F.2d 83 (D.C. Cir. 1974); see Dodd v. Spokane County, 393 F.2d 330, 335 (9th Cir. 1968); Robichaud v. Ronan, 351 F.2d 533, 536-38 (9th Cir. 1965).

68. Briggs v. Goodwin, 384 F. Supp. 1228 (D.D.C. 1974).

69. Brukhart v. Saxbe, 397 F. Supp. 499 (E.D. Pa. 1975).

70. 484 F.2d 602 (7th Cir. 1973), cert. denied, 415 U.S. 917 (1974).

71. Id. at 605 . 
motion to dismiss filed by the police officers, but dismissed the actions against the state's attorneys. ${ }^{22}$

On appeal, the Court of Appeals for the Seventh Circuit reversed the district court's dismissal of the case against the state's attorneys, disagreeing with the lower court's holding that the prosecutors were absolutely immune. ${ }^{73}$ The court looked closely at the alleged conduct to determine whether it was the type of "quasi-judicial" activity which is accorded immunity, or whether it was more closely akin to police investigatory activity ${ }^{74}$ Rejecting the argument of the state's attorneys that evidence gathering through such a raid "is so closely related to the presentation of evidence at trial that it should also be clothed with immunity," "75 the court held that planning and executing the raid has no greater immunity than other police activities. ${ }^{78}$

The functional approach illustrated in Hampton and inore recent cases $^{77}$ is consistent with the holding in Scheuer: if police officers and executive officials are protected by only a qualified immunity, and judges still enjoy absolute immunity, then the scope of prosecutorial immunity should depend on how closely the challenged activity is linked to the purely judicial process. No government official has ever been immune from liability for private or personal torts by virtue of his office, ${ }^{78}$ and the inquiry into whether the challenged act was annong those protected official duties inust be made in every case. ${ }^{79}$ Moreover, granting an absolute immunity to prosecutors for acts normally within the sphere of police function might encourage an unhealthy assunption of new roles by zealous district attorneys.

The functional approach, then, provides a sensible way to examine the questions left after Scheuer. This approach, lowever, is not free

72. See id. at 605-06.

73. Id. at 607 . The district court had relied on the Illinois Tort Inınunity Act, ILL. ANN. STAT. ch. 85, §§ 1-101 et seq. (Smith-Hurd 1966), to dismiss the action. The court of appeals first held that state officials cannot be immunized against a section 1983 claim by a state statute, 484 F.2d at 607 , and went on to hold that the state's attorneys could not invoke an absolute common law immunity in these circumstances. Id. at 609.

74. Id. at 608.

75. Id. at 609 .

76. Id. The court noted that the prosecutors' conduct might be characterized in various ways. The complaints might have been read as charges that the state's attorneys planned to have the police kill the victims. Id. at 608 . The defendants, on the other hand, urged that they were "charged with nothing more than the drafting of a search warrant which the raiding officers executed . . . " Id.

77. See cases cited in notes 65-69 supra.

78. PROSSER 987.

79. Even judges can claim no immunity for acts done totally in the absence of jurisdiction. Bradley v. Fisher, 80 U.S. (13 Wall.) 335, 350-52 (1871); see McGlasker v. Calton, 397 F. Supp. 525 (M.D. Ala. 1975). 
from problems. First, there may be considerable difficulty in drawing the line between the judicial (and thus absolutely protected) function of the prosecutor and those activities more properly classed with his executive function. It should be recalled that the state's attorneys in Hampton argued that the apartment raid was part of their evidence-gathering function which could not be separated from the presentation of evidence at trial. ${ }^{80}$ Where the challenged conduct is perjury or the actual direction of an investigation, the functional approach operates smoothly. As cases involving the questioning of potential witnesses or defendants, plea bargaining, or calendaring trials, for example, reach the courts, the linedrawing may become extremely difficult. Furtherinore, an unduly restrictive scope of absolute immunity might have a distorting impact on the way a prosecutor performs his duties. ${ }^{81}$

A nuch more difficult problem with the functional approacli is highlighted by the Hilliard and Imbler cases discussed above. ${ }^{82}$ Both involved conduct which could in no way be characterized as part of a prosecutor's executive, as opposed to judicial duties. Neither eliciting testimony at trial nor the decision on what evidence should be introduced at trial can be termed anything but intimately related to the judicial process. Correctly applying the functional approach, the Imbler majority deemed Prosecutor Pachtman's acts "an 'integral part of the judicial process," "83 and granted him absolute inununity. But the Imbler dissent ${ }^{84}$ and the Sixth Circuit in Hilliard ${ }^{85}$ would not permit the prosecutor to enjoy an absolute immunity in the performance of these activities. Such improper conduct, said the judges, was entirely outside the scope of a prosecutor's duties. ${ }^{86}$

This conclusion is a misapplication of the functional approach and of the Scheuer rationale, and illustrates that the functional approach cannot provide a satisfactory answer to the question of the appropriate scope of prosecutorial immunity. Looking to the propriety of the challenged conduct to determine whether it is "quasi-judicial" and thus

80. See note 75 supra and accompanying text.

81. Thus, if a prosecutor knows that he is absolutely immune for certain courtrooinrelated activities, he might be encouraged to concentrate on that part of his job, to the detriment of those executive functions which he should also perform.

82. See notes 40-53 supra and accompanying text.

83. 500 F.2d at 1302, quoting Marlowe v. Coakley, 404 F.2d 70 (9th Cir. 1968); see Grow v. Fisher, 523 F.2d 875 (7th Cir. 1975) (decision to prosecute within scope of "prosecutorial discretion").

84. 500 F.2d at 1304 (Kilkenny, J., dissenting).

85. Hilliard v. Williams, 516 F.2d 1344 (6th Cir. 1975).

86. Id. at 1350; Imbler v. Pachtman, 500 F.2d 1301, 1306 (9th Cir.) (Kilkenny, J., dissenting), cert. granted, 420 U.S. 945 (1975). 
absolutely protected misses the point. Certainly, any type of misconduct cannot be said to fall within a prosecutor's legitimate dutiesquasi-judicial or executive. Accordingly, distinguishing on this basis between acts that fall inside and those that fall outside the protected sphere becomes useless as a guide for courts or prosecutors. ${ }^{87}$

Such an analysis is too narrow. It is not helpful to distinguish between conduct which is proper and that which is not. 88 Single acts do not define the boundaries of a prosecutor's duties; rather, the boundaries are defined in broader terms. If an analysis based on public policy tends to provide a justification for absolute immunity for all public officials, ${ }^{89}$ the Hilliard analysis moves too far in the other direction and tends to provide a justification for renıving absolute immunity froin all public officials. Moreover, using the propriety of the challenged conduct as the litmus for determining whether an absolute or a qualified immunity will apply is inappropriate because it fails to face up to the clear implication of Scheuer. There are specific incidences of prosecutorial conduct which the courts are no longer disposed to shield with an absolute immunity, but those acts occur both in the executive and the judicial capacities of the prosecutor. In Hilliard, the court fashioned an unworkable distinction based on an after-the-fact examination of the propriety of the challenged conduct in order to remove the immunity for acts which were clearly entwined with the judicial process itself. It should have squarely confronted the question left open by Scheuer, and decided that prosecutors are to be afforded only a qualified immunity.$^{00}$ Such a result would be consistent with the trend away froin absolute official immunity that Scheuer reflects. ${ }^{91}$

87. An argument similar to that proposed in Hilliard has been made in the context of respondeat superior in tort law. Masters often contend that it was not in the scope of their servants' duties to act negligently; hence the master should not be held vicariously liable. These contentions have not been accepted, and masters cannot escape liability on these grounds. See Prosser $\& 70$, at 461 . Similarly, a master is liable for the intentional tort of his servant "where its purpose, however misguided, is wholly or in part to further the master's business." Id. at 464. See generally Brill, The Liability of an Employer for the Wilful Torts of His Servants, 45 CHI.-KENT L. REv. 1 (1968).

88. Judge Leamed Hand criticized a similar argument. "A moment's reflection shows, however, that that cannot be the meaning of the limitation without defeating the whole doctrine." Gregoire v. Biddle, 177 F.2d 579, 581 (2d Cir. 1949), cert. denied, 339 U.S. 949 (1950).

89. See text following note 64 supra.

90. Indeed, the result reached in Hilliard might be interpreted as granting only a qualified immunity to the prosecutor. If one reads the court's holding that the deliberate withholding of exculpatory evidence is an act in bad faith, the result would have been the same as that reaclied on a qualified immunity analysis. The court, however, does not speak in terms of good faith.

91. See notes 36-39 supra and accompanying text. 
The proper inquiry, then, is not into the specific acts of a prosecutor in any given case, but into the total prosecutorial function. After Scheuer it is clear that the modern policy rationale alone does not justify an absolute immunity for any government official. To determine whether a prosecutor should be entitled to an absolute immunity derived from the judicial attributes of his office, his role nust be examined in light of the historical justifications for judicial-as opposed to executive-immunity.

\section{The Historical Foundations of Judicial Immunity}

The doctrine of absolute judicial immunity has been established at least since $1607,{ }^{92}$ and some elements of the concept were formulated two centuries prior to that date. ${ }^{83}$ Since that time there have been no substantial changes in the rule, which was recognized by the United States Suprenre Court in 1871.84 An examination of the early English cases suggests two broad characteristics of the judicial officer's role which guided the original developnent of the absolute imnunity doctrine. In order to decide whether the prosecutor falls within the scope of the doctrine, it should be determined whether his duties possess those two characteristics. First, however, a brief sketcli of the historical justifications for judicial imnunity is in order.

In the very early conimon law the judicial imnunity doctrine was not recognized at all. ${ }^{95}$ When the concept did gain acceptance, its basis

92. See Floyd v. Barker, 77 Eng. Rep. 1305 (K.B. 1607).

93. See 6 HoLDSWORTH 235-36.

94. Bradley v. Fisher, 80 U.S. (13 Wall.) 335 (1871). The first Supreme Court case to deal with the doctrine of judicial immunity was Randall v. Brigham, 74 U.S. (7 Wall.) 523 (1868). In that case the Court held that it was a "general principle applicable to all judicial officers, that they are not liable to a civil action for any judicial act done within their jurisdiction." Id. at 535. Some crucial elements of the common law doctrine relating to jurisdiction vere not clearly accepted in Brigham, however, and it was not until the Bradley decision that it was explicit that the same common law doctrine that had been developed in England would also be the law in the United States.

95. 6 HoLDSWORTH 234-35. Since there was nothing that could properly be called an appeal from court to court known to the early common law, a principal means of attacking a judgment of an inferior court was a complaint against the judge. The procedure involved what was known as a complaint of false judgment. The unsuccessful litigant would first obtain a writ which generally commanded the sheriff to have a record made of the proceedings; then the record would be presented to the justices of the superior court and a debate would ensue, not between the two original litigants, but between the complainant and one or more representatives of the inferior court. Finally, it was up to the justices to decided whether the inferior court's judgment should stand. If the justices decided that the judgment of the inferior court should be annulled, the court was forced to pay damages to the complainant and the judge sometimes lost the right to hold court. See id. at 213-14 \& n.1, 235; 2 F. Pollock \& F. MAITLAND, The History of ENGLISH LAW 664, 666-67 (2d ed. 1923). 
was formulated in terms of the sanctity of the records of courts of record.9 ${ }^{98}$ The distinction between courts that maintained official records and those that did not began to fade following the 1607 decision by Lord Coke in Floyd $v$. Barker ${ }^{97}$ In that decision, the rationale for absolute judicial immumity was couched for the first time in terms of what now are deemed traditional pohicy arguments. Coke noted that, "insomuch as the Judges of the realm have the administration of justice, under the King, to all his subjects," they should not be answerable before another court, regardless of their good faith or motives, ${ }^{98}$ "for they are only to make an account to God and the King, and not to answer to any suggestion in the Star-Chainber." ${ }^{99}$ The reasons for that conclusion sound as if they were written today: "[F]or this would tend to the scandal and subversion of all justice. And those who are the most simcere, would not be free from continual calumniations . . . ."100

By the early to mid-nineteenth century, courts were able to state that it was a principle of the law that no action would lie against a superior court judge for any judicial act, even though it was alleged that he had acted with a malicious motive. ${ }^{101}$ While this shift to a public pol-

96. In contrast to "courts not of record," the courts of record maintained rolls of the proceedings which were considered "such high and super-eminent authority" that their truth could not be called into question. 3 W. Blackstone, Commentaries on tHe LAwS OF ENGLAND 24 (16th ed. 1825). To prevent any questioning of the record itself, judges were protected from any liability for acts done during the trial. 5 HoLDsworth 157-58; 6 HoLDsworth at 235; cf. Floyd v. Barker, 77 Eng. Rep. 1305 (K.B. 1607). For a discussion of the political reasons behind the emphasis upon distinctions between courts of record and courts not of record, see 5 HOLDSWORTH 157-60.

97. 77 Eng. Rep. 1305 (K.B. 1607).

98. Id. at 1307 ("[T]he reason ... why a Judge, for anything done by him as Judge, . . . shall not be drawn in question before any other Judge, for any surmise of corruption, except before the King himself, is for this; the King himself is de jure to deliver justice to all his subjects; and for this, that he himself cannot do it to all persons, he delegates his power to his Judges . . . .") (emphasis added).

99. Id.

100. Id.

101. See Fray v. Blackburn, 122 Eng. Rep. 217 (K.B. 1863) (allegation that judge maliciously refused to impose costs upon the losing party in earlier trial); Scott v. Stansfield, L.R. 3 Ex. 220 (1868) (slander); Taaffe v. Downes (Ire. C.P. 1813), reprinted, Calder v. Halket, 13 Eng. Rep. 12, 15 n.(a) (P.C. 1840) (assault and false imprisonment). The holding and rationale of Floyd v. Barker had been strengthened throughout the seventeenth and eighteenth centuries. For example, in the frequently cited case of Hamond y. Howell, 86 Eng. Rep. 1035 (K.B. 1677), it was held that, although it had been judicially determined that a judge's actions were illegal, a civil action for damages would not lie against him. The point takes on added significance in light of the facts of the case: the judge involved was merely a magistrate who, however, was performing acts in the character of a judge. "[T]he bringing of the action," said the court, "was a greater offence than the fining of the plaintiff, and committing of him for 
icy rationale for absolute judicial immunity is unquestioned, it is important to recognize that it occurred gradually. In Floyd v. Barker, for example, although the case was decided on public policy grounds, the court was nonetheless quick to point out that a court of record was involved in the case. ${ }^{102}$

The early emphasis on sanctity of the records in the development of judicial immunity suggests the first important attribute of the judicial process which should be examined. The origins of absolute immunity for judges lay in the need to protect the formality, and lience the legitimacy, of judicial proceedings. In the courts of record, the proceedings were "enrolled for a perpetual nemory and testimony," ${ }^{103}$ were open to the public, and were conducted in a formal setting. A dissatisfied suitor could, of course, attack the record by writ of error through the early appeals processes, ${ }^{104}$ but "the common law had learnt to draw a distinction between the correctness of a judge's decision and the rectitude of his conduct." ${ }^{105}$ To permit an unhappy litigant to go behind the record and challenge the judge's conduct of the proceedings would undermine the dignity of the process ${ }^{108}$ and damage the claim of the common law courts to legitimacy as a inechamisin for the resolution of disputes.

As noted above, the common law courts continued to take cognizance of the distinction based on formal records long after Floyd $v$. Barker signaled the shift to a inodern public policy rationale. ${ }^{10 r}$ This reluctance to discard the distinction apparently was unnecessary to mamtam the formality and dignity of court proceedings once judicial

non-payment; and . . it was a bold attempt against the Government and justice in general." Id. at 1036-37; accord, Groenvelt v. Burwell, 91 Eng. Rep. 1202 (K.B. 1700).

102. Floyd v. Barker, 77 Eng. Rep. 1305, 1306-07 (K.B. 1607). Holdsworth points out, however, that Lord Coke, in his opinion, "was exaggerating" the distinction "in order to use it as one of the foundations of his arguments for the supremacy of the common law, and as a means to depress such rival courts as the court of Admiralty, and the ecclesiastical courts." 5 HoLDSwORTr 159-60. It can thus be argued that political, and not practical or historical, reasons underlay the maintenance of the distinction. See id.

103. The Drctionary of ENGLish LAw 526 (E. Jowitt ed. 1959).

104. See 6 HOLDSWORTH 236.

105. Id, at 235; see 2 F. Pollock \& F. Martland, supra note 95, at 668-69.

106. For a discussion of the importance of the dignity of the proceedings, see. Taaffe v. Downes (Ire. C.P. 1813), reprinted, Calder v. Halket, 13 Eng. Rep. 12, 15 n.(a), at 18 (P.C. 1840).

107. In Rex v. Skinner, 98 Eng. Rep. 529 (K.B. 1772), counsel for a judge charged with slandering a grand jury referred to the fact that a court of record was involved. In Groenvelt v. Burwell, 91 Eng. Rep. 1202, 1211-12 (K.B. 1700), the court stressed the fact that a court of record was involved, although the power of the court to fine and imprison was the key inquiry. 
immunity was justified on policy grounds, and may be explained by political considerations. ${ }^{108}$ Even if the records were absent, the principal elements which contributed to their "sanctity"-decision-making in a formal setting, a forum open to public inspection, the presentation of all sides of an issue, and proceedings witnessed by all parties in interest-remained.

To determine if prosecutors should be entitled to an absolute immunity on the basis of a similar need to protect the dignity and formality of prosecutorial functions, those functions must be closely scrutinized. It is clear that many of the activities which fall within the sphere of the prosecutor's duties do not involve anything near the formality which is inherent in any judicial proceeding. It is not unusual for a statute to give the prosecutor responsibility for reviewing evidence, imstituting proceedings, drawing up indictments, and conducting criminal trials. ${ }^{109}$ In order to carry out those tasks, the prosecutor must engage in a number of activities which, though not expressly provided for in a statute, are undeniably included within the scope of his duties. For instance, the duty to conduct criminal trials involves such activities as interviewing witnesses, conducting investigations in preparation for trial, collecting evidence, conducting depositions and other modes of discovery, as well as the actual questioning of witnesses at the trial itself. ${ }^{110}$

Most of these activities necessarily are not conducted with a high degree of formality, and it is not suggested here that they should be. To the contrary, efficient performance of these activities requires far less formality. What is meant to be suggested is that such activities present more opportunities for concealed errors and misconduct than does a formal judicial proceeding, thus permitting the question whether the same degree of protection that was established originally to protect the sanctity of the records should be afforded officials who do not operate under the same degree of openness and formality. Moreover, the prosecutorial role is essentially that of an advocate and not that of an impartial arbiter of disputes. The need to protect the dignity and legitinacy of the prosecutor's function does not seein nearly so weighty as does the same need in the context of the judicial function. Thus, prosecutors should not be entitled to an absolute immunity on the basis of this characteristic of the judicial process.

108. See note 102 supra.

109. See, e.g., CAL. Gov't CODE $\$ \S 26500-02$ (West 1968).

110. See generally 1 \& 2 MANual for Prosecuting Attorneys (M. Ploscowe ed. 1956). 
The second important characteristic of traditional absolute judicial immunity was the requirement that the official seeking protection from civil suit have performed a "judicial act." Although the formal distinction between courts of record and those not of record was early displaced by a modern public policy rationale, and the scope of judicial immumity for judicial acts and opinions performed within the officer's jurisdiction was broad, ${ }^{111}$ the sine qua non of the doctrine remained the requirement that a judicial act be performed. ${ }^{112}$ Whether there are special attributes of the "judicial act" which justify an absolute immunity for judges apart fron the modern public policy rationale is not clear. Unless and until the Supreme Court undertakes to review its decision in Pierson v. Ray, ${ }^{113}$ however, it must be assumed that "judicial acts" are entitled to an absolute protection.

The common law understanding of the term required an act, upon consideration of facts and circumstances, which imposed hability or affected the rights of others. ${ }^{114}$ Does the prosecutor, then, perform

111. The immunity was applied not only to judges of courts of general and superior jurisdiction, but equally to those of inferior courts of limited jurisdiction. See notes 96102 supra and accompanying text. Thus, the rule exempted from liability not only judges of the superior common law courts, but also equity judges, justices of the peace, and coroners. See, e.g., Dicas v. Brougham, 174 Eng. Rep. 106 (Ex. 1833) (equity judges); Harman v. Tappenden, 102 Eng. Rep. 214 (K.B. 1801) (quasi-judicial officers of fishermen's guild); Rex v. Cox, 97 Eng. Rep. 562 (K.B. 1759) (justices of the peace); Thomas v. Churton, 121 Eng. Rep. 1150 (Q.B. 1862); Garnett v. Ferrand, 108 Eng. Rep. 576 (K.B. 1827) (coroners). The coroner at common law held a much more significant office than does his counterpart in the United States today. He exercised more power, and the coroner's court was one of record. It was well settled in the common law that in holding an inquest the coroner was performing a judicial duty. See also Duke of Newcastle v. Clark, 129 Eng. Rep. 518, 530 (C.P. 1818) (still another extension of the doctrine).

112. That requirement was, of course, carried over into the American case law. See, e.g., Randall v. Brigham, 74 U.S. (7 Wall.) 523, 535 (1868) ("judicial officers . . . are not liable . . . for any judicial act done within their jurisdiction"); Griffith v. Slinkard, 146 Ind. 117, 122, 44 N.E. 1001, 1002 (1896) ("no public officer is responsible . . . for a judicial determination, . . . however malicious the motive which produced it").

113. 386 U.S. 547 (1967).

114. See The Queen v. Corporation of Dublin, 2 L.R. Ir. 371, 376-77 (1878). Similar definitions are found in many worls and cases. See 1 J. Bouvier, Bouvier's LAW Dictionary and Concise ENCYClopedia 116 (8th ed. F. Rawles 3d rev. 1914) ("[A judicial act is] [a]n act performed by a court touching the rights of parties or property brought before it . . . by ministerial acts." This definition is too narrow in one sense since it refers to acts performed by a court, and it is clear that even in the early common law judicial acts were deemed to be performed by non-judges.); $c f$. The Queen v. Local Gov't Bd. for Ire., 2 Ir. R. 349, 383 (1902) (defining judicial acts as those "done in the exercise, or assumed exercise, of jurisdiction, as distinguished from any other authority") (emphasis in original); In re Local Gov't Bd., 16 L.R. Ir. 150, 159 (1885). See also $2 \mathrm{~T}$. Cooley, A Treatise on the Law of TorTs 795 (3d ed. 1906). 
"judicial acts" as they were known to the common law? It has been noted that many cases tend to state the prosecutor's function in conclusory terms. ${ }^{115}$ Some courts have been more specific, holding that the prosecutor, in deciding whether a particular prosecution shall be imstituted or followed up, performs much the same function as a grand jury, which is protected by absolute immumity in common law actions. ${ }^{116}$ The

115. See Yaselli v. Goff, 12 F.2d 396, 404 (2d Cir. 1926), aff'd per curiam, 275 U.S. 503 (1927) (where the reference was simply to the fact that the prosecutor "exercises important judicial functions").

116. See Downey v. Allen, 36 Cal. App. 2d 269, 97 P.2d 515 (1939); Smith v. Parman, 101 Kan. 115, 165 P. 663 (1917). (There apparently are no reported section 1983 actions.) Accordingly, it has been argued that prosecutors should be protected by absolute immunity owing to the close analogy between prosecutorial functions and those of the grand jury. See Yaselli v. Goff, 12 F.2d 396, 403 (2d Cir. 1926), aff'd per curiam, 275 U.S. 503 (1927). Despite the similarities, the differences between the nature of the prosecutorial function and the grand jury function are significant for iminunity purposes. Acting as "an arm of the court," the grand jury proceeds in a formal setting, determines the facts, and is einpowered to indict. These functions have been held to constitute a judicial inquiry. Levine v. United States, 362 U.S. 610, 617 (1960). One of the most valuable functions of the grand jury has been to "stand between the prosecutor and the accused, and to determine whether the charge was founded upon credible testimony or was dictated by malice or personal ill will." Hale v. Henkel, 201 U.S. 43,59 (1906). In so doing, the grand jury stands in a position sinilar to that of the magistrate who determines probable cause prior to issuing a search or arrest warrant. The Supreme Court has stated that the main thrust of the fourth amendment is the protection that exists in its requirement that the inferences which inay be drawn from evidence "be drawn by a neutral and detached magistrate." Johnson v. United States, 333 U.S. 10, 14 (1948). As the magistrate protects against the overzealous police officer, the grand jury acts as a "neutral and detached" body which serves as a watchdog over the sometimes overzealous prosecutor. Thus, although the grand jury does not determine final liability in the same fashion as does a judge, it appears to affect rights much more intimately than does a prosecuting attorney. Moreover, the grand jury exists as an arm of the court while the prosecutor is related to the court only insofar as every attorney is so associated. See note 121 infra and accompanying text. But cf. Bricker v. Michigan Parole Bd., 18 CRIM. L. REP. 2362 (E.D. Mich. Dec. 18, 1975).

Even if the grand jury does not perform "judicial acts" so as to bring it within the protection of judicial immunity, there is a separate rationale for its absolute inmunity. There has been a long-standing policy in the law that grand jury proceedings should be conducted in secret. Pittsburgh Plate Glass Co. v. United States, 360 U.S. 395, 399 (1959); United States v. Procter \& Gamble Co., 356 U.S. 677, 681 (1958). Secrecy would, to a large extent, be destroyed if grand jurors were not shielded from civil suits insofar as any proof of an allegation would entail disclosure of what occurred during the grand jury proceedings. It has been said that "[n]othing could be more destructive of the workings of our grand jury system or more hostile to its historic status," than to allow intrusion into the "indispensable secrecy of grand jury proceedings." United States v. Johnson, 319 U.S. 503, 513 (1943). The purposes of the secrecy requirement include: (1) a desire to keep the grand jury a "dispassionate forum," free from external pressures, (2) an assurance that witnesses will testify freely, (3) a need to protect innocent persons from intimidation, and (4) the necessity of protecting all persons who appear before one-sided hearings, without opportunity to reply. See, e.g., United States v. Consolidated Laundries Corp., 159 F. Supp. 860, 866 (S.D.N.Y. 1958); Coblentz v. 
prosecutor's "judicial functions" do not, however, appear to be of the type that impose liability or affect the rights of others in the sense that the functions of a judge do so. It is true that a prosecutor has enormous discretionary power in deciding whether or not an individual who has been arrested should be prosecuted, ${ }^{117}$ and that "the decision whether to file formal charges is a vitally important stage in the criminal process." ${ }^{118}$ Nevertheless, such a decision does not appear to be a judicial act as known to the common law. It does not initially impinge upon the rights of the defendant who lias already been arrested by the police, ${ }^{110}$ nor does it inipose final liability on the defendant since a grand jury must determine if there exists probable cause for the prosecution, and a trial judgment must be had before there is any final liability imposed. ${ }^{120}$ Moreover, most cases have indicated that the prosecutor is an officer of the court only to the extent that all attorneys are officers of the court and that lie is not a part of the court by virtue of his office. ${ }^{121}$

State, 164 Md. 558, 566-67, 166 A. 45, 49 (1933). Indeed, in the federal system, the secrecy requirement has been embodied in statute. See FED. R. CRIM. P. 6(e).

117. See notes $122-30$ infra and accompanying text.

118. The President's Commission on Law Enforcement and Administration op JUSTICE, TASK ForCe RePORT: THE COURTS 5 (1967).

119. For a discussion of the discretionary aspects of police work, see $\mathrm{K}$. Davis, Police Discretion (1975). See also Goldstein, Police Discretion Not to Invoke the Criminal Process: Low-Visibility Decisions in the Administration of Justice, 69 YALE L.J. 543 (1960); LaFave, The Police and Nonenforcement of the Law (pts. 1-2), 1962 Wis. L. REv. 104, 179; McGowan, Rule-making and the Police, 70 Micr. L. REv. 659 (1972); Tieger, Police Discretion and Discriminatory Enforcement, 1971 DuKe L.J. 717.

It might be argued that a prosecutorial decision not to prosecute imposes final liability just as a judge's dismissal of charges or a jury's not-guilty verdict does. Some section 1983 claims against prosecutors have been based on alleged failures to take action. Grow v. Fisher, 523 F.2d 875 (7th Cir. 1975) (failing to prosecute assault charges); cf. Curry v. Jensen, 523 F.2d 387, 388 (9th Cir. 1975) (charging a misdemeanor rather than a felony). Such an argument has considerable appeal; however, the same reasoning might be applied to the decision of a policeinan not to arrest and thus be the basis for an absolute immunity for all police officers.

120. See, e.g., Y. KAmisar, W. LAFAve \& J. Israel, Modern Criminal Procedure 415 (4th ed. 1974). Even in those states which initiate criminal proceedings by having the prosecutor file an information with the trial court, the defendant has been afforded a preliminary hearing to determine probable cause. Id. at 9-10.

121. See Fleming v. Hance, 153 Cal. 162, 94 P. 620 (1908); State v. DeStasio, 49 N.J. 247, 260 n.2, 229 A.2d 636, 634 n.2, cert. denied, 389 U.S. 830 (1967); MoDonald v. Goldstein, 273 App. Div. 649, 79 N.Y.S.2d 690 (1948). It has been held that public officials enjoy no immunity from suit solely by virtue of their relationship to the judicial system. McCray v. Maryland, 456 F.2d 1, 3-4 (4th Cir. 1972); Scarrella v. Spannaus, 376 F. Supp. 857, 859 (D. Minn. 1974).

Some courts have indicated that the prosecuting attorney is a member of the executive branch of government, and hence has no greater connection. with the judicial branch than being the foremost representative of the executive in the enforcement of the criminal law. See, e.g., People v. Goodspeed, 22 Cal. App. 3d 690, 705 n.4, 99 Cal. 
Another argument, which draws on the discretion notions of the modern public policy rationale, might be advanced in support of a prosecutor's claim to the performance of "judicial acts." Prosecutors, like other quasi-judicial officers, exercise a broad discretion in the performance of their duties. ${ }^{122}$ The most significant aspect of that discretion, of course, is the power to decide whether or not to prosecute a particular defendant at all. ${ }^{123}$ It can be urged that the discretion available to a prosecutor in deciding whether to prosecute makes his decision an act in the nature of one performed by a judge. ${ }^{124}$

That a prosecutor "can exercise so large an influence on dispositions that involve the penal sanction, without reference to any norms but those that they may create for themselves" 125 is a matter of concern. How does the prosecutor go about exercising such a large influence? ${ }^{120}$ How does he handle his discretionary power? The following questions liave been suggested as some of the ones the prosecutor considers: What would be the result of a prosecution? Would it be a waste of time? Would it be expensive to the state? Would it be unfair to the defendant? Would it serve any good purpose to society in general? Would it liave good publicity value? Would it cause political problems? If the offender is a friend, would it be a fair thing to do to him? ${ }^{127}$

These types of questions indicate the number of pragmatic considerations the prosecutor deals with before making a decision whether or not to prosecute. The predominance of these practical matters distin-

Rptr. 696, 706 n.4 (1972); State v. Winne, 12 N.J. 152, 96 A.2d 63 (1953). Of course, most quasi-judicial officers are nominally members of the executive branch. Other courts, indeed some legislatures, have deemed the prosecutor to be a member of the jndicial branch. E.g., Cawley v. Warren, 216 F.2d 74, 76 (7th Cir. 1954).

122. For an interesting discussion of the extent and nature of discretionary immunity in general, including both the judicial and quasi-judicial aspects, see Jaffe, Damage Actions, supra note 2, at 218-25.

123. See F. Miller, Prosecution-The Decision to Charge a Suspect with A CRIME 154-345 (1970).

124. Cf. 2 T. COOLEY, supra note 114 , at 799-800.

125. Wechsler, The Challenge of a Model Penal Code, 65 HaRv. L. Rev. 1097, 1102 (1952).

126. A number of authors have commented upon the practice of the prosecutor. See, e.g., Arnold, Law Enforcement-An Attempt at Social Dissection, 42 YALE L.J. 1 (1932); Baker, The Prosecutor-Initiation of Prosecution, 23 J. AM. INsT. CRuM. L. \& Criminology 770 (1933); Brezner, How the Prosecuting Attorney's Office Processes Complaints, 27 DeTrort LAW. 3 (1959); Freedman, The Professional Responsibility of the Prosecuting Attorney, 55 Geo. L.J. 1030 (1967); Kaplan, The Prosecutorial Discretion-A Comment, 60 Nw. U.L. Rev. 174 (1965); Uviller, The Virtuous Prosecutor in Quest of an Ethical Standard: Guidance from the A.B.A., 71 Mich. L. REv. 1145 (1973). See generally Y. KAMISAR, W. LAFAVE \& J. IsRaEL, supra note 120, at 803-64; F. MILLER, supra note 123.

127. Baker, supra note 126 , at $770-71$. 
guishes the prosecutor's discretion from the judge's. ${ }^{128}$ The judge, to be sure, must also contend with a great many practical considerations; however, the practical considerations dealt with by the judge are of a different nature. The judge often considers such questions as whether the trial would be a burden upon the courts or whether a particular judicial action would serve a beneficial purpose for society in general. It is clear, though, that he does not face the same types of external pressures and pragmatic considerations which arise every day in the prosecutor's office. Furthermore, those questions he does consider are merely ancillary to the general power vested in him to impose liability or affect the rights of the parties before him. Because the prosecutor does not have that general power, his discretion in regard to whether the machinery of the state's criminal processes should be put into motion is more closely related to that of the private attorney who must face similar pragmatic considerations in deciding whether it would be worthwhile to bring a civil action on behalf of his chent. If then, as the precedent seems to indicate, the availability of an absolute immunity for a quasijudicial official should turn on whether his discretion is of such a nature that it imposes liability or affects the rights of others, ${ }^{129}$ the prosecutor cannot claim such protection. ${ }^{130}$

128. See Bauers v. Heisel, 361 F.2d 581, 594 (3d Cir. 1966) (Freedman, J., dissenting), cert. denied, 386 U.S. 1021 (1967).

129. In an action brought against a coroner, for example, it was pointed out that the coroner did not act judicially "in holding an inquest, which is a mere finding and does not establish rights, and therefore his authority lacks the first element of judicial power." Delatte v. Genovese, 273 F. Supp. 654, 658 (E.D. La 1967), quoting 18 AM. JUR. 2D Coroners or Medical Examiners $\$ 8$ (1965); accord, Stults v. Board of Comm'rs, 168 Ind. 539, 81 N.E. 471 (1907); Cox v. Royal Tribe of Joseph, 42 Ore. 365, 71 P. 73 (1903).

130. It is important to note another distinction consistently observed by common law courts between superior and inferior court judges, and the scope of the immunity afforded each. It was clear that neither was protected for acts performed completely outside his jurisdiction. See 6 HOLDSwORTH 236. It was recognized that "[i]n such a case the matter was not coram judice, the record could be traversed, and the judge was not protected from the aggrieved litigant's action." Id. See also Bradley v. Fisher, 80 . U.S. (13 Wall.) 335, 351-52 (1871). The distinction arose when the judge acted merely in excess of his jurisdiction rather than wholly in the absence thereof. An act in excess of jurisdiction was one in which the judge had jurisdiction over the subject matter of a case, but exceeded his jurisdiction in regard to the persons over whom he had the power to adjudicate or the punishments he had the power to impose. A superior court judge was shielded by absolute immunity for such acts, his jurisdiction being presumed. See Doswell v. Impey, 107 Eng. Rep. 61 (K.B. 1823) (commissioners of bankrupts not liable for false imprisonment); Ackerley v. Parkinson, 105 Eng. Rep. 665 (K.B. 1815) (ecclesiastical judge not liable for excommunication); Groenvelt v. Burwell, 91 Eng. Rep. 1202 (K.B. 1700) (censors of College of Physicians not liable for determination of malpractice and imprisonment that followed). An inferior court judge was not so protected. See Peacock v. Bell, 85 Eng. Rep. 84 (K.B. 1667) (jurisdiction of inferior 


\section{CONCLUSION}

\section{The question posed at the outset of this Note was the extent to}

courts is limited by definite restrictions of subject matter, persons, or place, nothing being intended to be within the inferior courts' jurisdiction but that which is expressly alleged); Winford v. Powell, 92 Eng. Rep. 357 (K.B. 1712). Consequently, in a case in which both the superior and inferior court judges had subject matter jurisdiction, but neither had jurisdiction over the parties, the superior court judge would be iminune from civil suit while the inferior court judge would not. Perkin v. Proctor, 95 Eng. Rep. 874 (K.B. 1768); Morse v. James, 125 Eng. Rep. 1089 (C.P. 1738); see 6 HoLDsworTH 23840. Contra, McDaniel v. Harrell, 81 Fla. 66, 87 So. 631 (1921); Calhoun v. Little, 106 Ga. 336, 32 S.E. 86 (1898); Thompson v. Jackson, 93 Iowa 376, 61 N.W. 1004 (1895); Robertson v. Parker, 99 Wis. 652,75 N.W. 423 (1898). The latter cases indicate that the rule has not been universally accepted in the United States, and the trend of authority has been that the same considerations that applied to superior court judges should also apply to inferior court judges. See McGlasker v. Calton, 397 F. Supp. 525, 529-30 (M.D. Ala. 1975). The case of Calder v. Halket, 13 Eng. Rep. 12 (P.C. 1840), resulted in an uuusual holding. It was held that if the judge exceeds his jurisdiction because of a mistake of fact, it must be shown by the plaintiff that the true facts were either known, or ought to have been known, to him in order to be held hable. Otherwise the maxim ignorantia facti excusat was held to apply. No other case has been found which goes to such an extent.

The basis for the distinction was not clear in the English cases. One might surmise, although it was not explicitly stated, that it was a pragmatic consideration based on the fact that inferior court judges were answerable to higher authority, while superior court judges, as representatives of the King, were not. See Floyd v. Barker, 77 Eng. Rep. 1305, 1307 (K.B. 1607).

It has been suggested that a modern rationale bo grounded on the fact that an inferior court judge's decision may be appealed:

The inferior judicial officer is not excused for exceeding his jurisdiction because, a limited authority only having been conferred upon hiin, he best observes the spirit of the law by solving all questions of doubt against his jurisdiction. If he errs in this direction, no harm is done, because he can always be set right by the court having appellate authority over him, and he can have no occasion to take hazards so long as his decision is subject to review. 2 T. COOLEY, supra note 114 , at 811 .

Conversely, the superior court judge operates under a presumption that his duties should be exercised with more liberty of action. Id. at 811-12. The American cases that have discarded the distinction disapprove of Cooley's reasoning, and have contended that it is illogical for the law to protect the one judge and not the other. Some courts, however, have required that the inferior court judge act in good faith if he has exceeded his jurisdiction. Brooln v. Douglass, 175 Ala. 268, 57 So. 860 (1912); Thompson v. Jackson, 93 Iowa 376, 61 N.W. 1004 (1895); Grove v. Van Duyn, 44 N.J.L. 654 (1882); Robertson v. Parker, 99 Wis. 652, 75 N.W. 423 (1898).

In light of this long-adhered-to distinction, it must be recognized that the extension of the absolute immunity of judges for acts done within the jurisdiction of their courts into the area of quasi-judicial actions is not as facile as it might at first appear. It is clear that judges of the inferior courts did not have a shield of protection as broad as that afforded the superior court judges. Yet there can be no doubt that the inferior court judges were still, after all, judges and were performing judicial acts in a formal setting. See notes 103-08 supra and accompanying text. It does not seem to be at all so clear as most courts have supposed that an officer such as a prosecutor, in whoin, it is conceded, there rests broad discretionary power, would be afforded protection as broad as that of an inferior court judge. There appear to be no cases on the point at common law. 
which Scheuer $v$. Rhodes ${ }^{131}$ would redefine the scope of immunity for quasi-judicial officials in section 1983 actions. Two facts were clear immediately following Scheuer: (1) judges remained protected by absolute immunity, and (2) a long line of cases had extended that absolute immunity to shield prosecuting attorneys, used here as the model quasijudicial official.

In order to decide if a particular quasi-judicial official is absolutely immune from suit under section 1983, it appears necessary to determine whether his duties are of such a nature that he may be deemed a judicial official as that term was understood when the traditional judicial immunity doctrine was estabhshed. ${ }^{132}$ Under Scheuer, an executive officer who exercises discretion in the carrying out of his official duties is no longer protected by the same immunity as that which shields a judge. ${ }^{133}$

Nonetheless, it does not seem entirely logical to assume that the scope of protection afforded even an inferior court judge would be identical to that afforded a quasi-judicial officer, especially in light of the common law emphasis on formality of the proceedings and the understanding that a judicial act need be performed.

131. 416 U.S. 232 (1974).

132. Compare Burkes v. Callion, 433 F.2d 318 (9th Cir. 1970), cert. denied, 403 U.S. 908 (1971), with Delatte v. Genovese, 273 F. Supp. 654 (E.D. La. 1967).

133. The Supreme Court's present attitude toward section 1983 and toward limitation of the immunity defense should be viewed in light of other similar developments. It is clear that the present decade has produced a revival not only of section 1983 but also of other sections of the 1871 Civil Rights Act as well, particularly sections 1981 and 1982. Of course, the Court's opinion iu Jones v. Alfred H. Mayer Co., 392 U.S. 409 (1968), which construed the reach of section 1982, must be viewed as a landmark decision. Similarly, its decision in Tillman v. Wheaton-Haven Recreation Ass'n, Inc., 410 U.S. 431 (1973), and such lower court decisions as Guerra v. Manchester Terminal Corp., 498 F.2d 641 (5th Cir. 1974), made section 1981 a inuch more viable section in the general area of racial discrimination.

With regard to the Court's attitude toward immunity, one need only examine some of the cases decided and statutes passed in the 1960s which abolished tort immuuity for municipalities to obtain a sense of the judicial mood on the issue. There began during that period "a minor avalanche of decisions repudiating municipal immunity," creating "a radical change in the law." Prosser $\S 131$, at 985 . In one of the most widely cited cases, Muskopf v. Coming Hosp. Dist., 55 Cal. 2d 211, 359 P.2d 457, 11 Cal. Rptr. 89 (1961), modified, 57 Cal. 2d 488, 370 P.2d 325, 20 Cal. Rptr. 621 (1962), holding that no level of state or local government could rely upon governmental immunity as a defense against tort liability, the California Supreme Court recognized the erosion of immunity through previous statutory and judicial developments and pointed out that its decision was merely the "final step that carries to its conclusion an established legislative and judicial trend." 55 Cal. 2d at 221, 359 P.2d at 463,11 Cal. Rptr. at 95.

Other significant decisions in this area include Hargrove v. Town of Cocoa Beach, 96 So. 2d 130 (Fla. 1957), and Molitor v. Kaneland Community Unit Dist. No. 302, 18 IIl. 2d 11, 163 N.E.2d 89 (1959), cert. denied, 362 U.S: 968 (1960). Several statutes also abrogate governmental tort liability. E.g., CAL. Gov'T CODE $\$ \S 810$ to 996.6 (West 1966); ILL. ANN. STAT. ch. $85 \$$ 1-101 to 10-101 (Smith-Hurd 1966).

Arvo Van Alstyne has written a series of articles on the issue. Van Alstyne, 
Accordingly, the question should no longer be focused merely on the discretionary aspects of the duties, but also on whether these duties are of such a nature as to be deemed judicial acts. It has been shown that a prosecutor does not exercise such duties. ${ }^{134}$ The duties of other quasijudicial officials must be analyzed in the same manner to determine the scope of their immunity.

In light of the modern public policy rationale for official immunity, it seems clear that all governmental officials who must exercise discretion in carrying out the duties of their offices should be protected from civil suit by some type of immunity. In the case of those quasi-judicial officers, such as a prosecuting attorney, who do not perform acts which impose liability or affect the rights of others, the immunity to be afforded should be qualified. ${ }^{135}$ At least until there is evidence that a

Governmental Tort Liability: Judicial Lawmaking in a Statutory Milieu, 15 STAN. L. REv. 163 (1963); Van Alstyne, Governmental Tort Liability: A Public Policy Prospectus, 10 U.C.L.A.L. Rev. 463 (1963); Van Alstyne, Governmental Tort Liability: A Decade of Change, 1966 U. ILL. L.F. 919.

134. Because his office has been used as a model, it should be noted that the prosecutor presents some unique difficulties in terms of his immunity from suit. Although it has been suggested throughout this Note that the prosecutor should not receive absolute immunity from suit by virtue of his role as a quasi-judicial officer, it could be argued that he should be absolutely immune in his role as a participant in a judicial proceeding. That all participants in a judicial proceeding are absolutely immune in defamation actions is well established. See, e.g., Prosser $\S 114$; Veeder, Absolute Immunity In Defamation: Judicial Proceedings, 9 CoLUM. L. Rev. 463 (1909). In England, the same absolute immunity protects a barrister from being held liable for professional negligence during litigation. The iminunity extends to work done when litigation is pending, to acts performed while he is actually conducting the litigation, and to the drawing of pleadings. A recent case extended that immunity to a solicitor who conducted hitigation. Rondel v. Worsley, [1966] 3 All E.R. 657 (C.A.).

Absolute immunity for counsel in American law has not been extended beyond the area of defamation. Actions may be brought against attorneys for malicious prosecution and for malpractice, for example, indicating that the English doctrine of absolute immunity for attorneys in the conducting of litigation has not been accepted in this country. See 2 Practicing Law Institute, Professional Malpractice ch. I (1967); Drinker, Canons 28 and 29-An Appraisal, in Professional Negligence 240 (T. Roady \& W. Andersen eds. 1960); Wade, The Attorney's Liability for Negligence, in Professional Negligence 217 (T. Roady \& W. Andersen eds. 1960).

It appears, therefore, that a prosecutor would not be immune from section 1983 liability by virtue of his role as a participant in a judicial proceeding. It does appear that the possibility exists for a prosecutor to be liable under section 1983 and absolutely immune in a defamation suit for the same action committed during a judicial proceeding. In order for the possibility to arise, the plaintiff would have to allege that the prosecutor's remarks deprived him of a constitutional right. Martin v. Merola, Civil No. 75-7113 (2d Cir. Feb. 5, 1976); Williams v. Gorton, Civil No. 74-2627 (9th Cir. Jan. 19, 1976); Tunnell v. Wiley, 514 F.2d 971 (3d Cir. 1975).

135. Using a different analysis from that suggested in this Note, the Supreme Court has recently held that prosecutors are protected by an absolute immunity. Imbler $\mathbf{v}$. 
non-absolute immunity imposes undue restraint upon official conduct or deters good men from seeking office, it does not seem unreasonable to require quasi-judicial officers to act in good faith in the exercise of their discretion if they are to be exempt from a section 1983 suit. ${ }^{136}$ Indeed, as the Supreme Court has recognized, a good faith standard does not impose an unfair burden upon a person in a responsible public office which requires intelligence and judgment for the proper fulfillment of its duties. "Any lesser standard would deny much of the promise of $\S$ 1983."137

Pachtman, 44 U.S.L.W. 4250 (U.S. IMar. 2, 1976). See note 11 supra for a discussion of the decision's ramifications.

As noted above, see note 35 supra and accompanying text, the Scheuer Court recognized the importance of some type of immunity for executive officials. The decision to qualify that immunity, however, suggests that the Court considered unfounded fears that anything less than absolute immuuity "would seriously cripple the proper and effective administration of public affairs as entrusted to the executive branch of the government." Spalding v. Vilas, 161 U.S. 483, 498 (1896).

A qualified immunity for quasi-judicial officers would not be a totally new development, despite the strong precedent for absolute immunity in the federal courts. "The considerable majority of the state courts take the position that there is no immunity where the . . . officer does not act honestly and in good faith, but maliciously, or for an improper purpose," ProssER $\$ 132$, at 989 , even for those quasi-judicial officers who do exercise judicial acts. Those cases have recognized that if the challenged act committed is a judicial or quasi-judicial one, public policy requires that the quasi-judicial officer should not be forced to respond in dannages to a private individual for the honest exercise of his judgment, however erroneous that judgment might be. Nevertheless, "in matters of judgment and discretion they are liable ... if they act wilfully, corruptly, or maliciously." Vickers v. Motte, 109 Ga. App. 615, 618, 137 S.E.2d 77, 79-80 (1964), quoting Price v. Owen, 67 Ga. App. 58, 60-61, 19 S.E.2d 529, 531 (1942); accord, Tillotson v. Fair, 160 Kan. 81, 159 P.2d 471 (1945); Arnold v. Hubble, 18 Ky. L. Rptr. 947, 38 S.W. 1041 (1897); Taulli v. Gregory, 223 La. 195, 65 So. $2 d 312$ (1953); see McManis, supra note 30, at 825-31. Contra, Papagianakis v. The Samos, 186 F.2d 257 (4th Cir. 1950), cert. denied, 341 U.S. 921 (1951); Phelps v. Dawson, 97 F.2d 339 (8th Cir. 1938); Nadeau v. Marchessault, 112 Vt. 309, 24 A.2d 352 (1942).

136. See Prosser $\S 132$, at 989 ("no evidence of any uudue restraint of official conduct, or deterrence of good men from seeking office, in the states which do not recognize the absolute immunity on the part of inferior officers"); Jaffe, Damage Actions, supra note 2, at 216-17 (most officers who suffer any sort of liability are indemnified by the state).

137. Wood v. Strickland, 420 U.S. 308, 322 (1975). The Wood decision indicates the difficulties that were created by the Scheuer holding in regard to the definition of "good faith." The appropriate standard, according to the Wood majority, coutains elements of both a subjective and an objective test. The official must not only be acting in good faith, "with a belief that he is doing right," but also his actions cannot be justified by ignorance of "settled, indisputable law." Accordingly, if the official knew or reasonably should have known that his actions would violate a person's constitutional rights, or "if he took the action with the malicious intention" of violating constitutional rights, he should not be immune from section 1983 liability. Id. at 321-22. 